\title{
MENYINGKAP ILMU PERUBATAN MELAYU TRADISIONAL MENERUSI BEBERAPA MANUSKRIP TERPILIH
}

\author{
Arba'iyah Mohd Noor
}

\begin{abstract}
Large numbers of manuscripts on Malay traditional medicine in the Malay Archipelago are located in Malaysia as well as in few European libraries. This situation demonstrates that the Malay traditional medicine has been both practised and documented to be used as guidelines for the next generation. These medical manuscripts reflect the Malay's knowledge and expertise in identifying types of diseases, remedies, and its subsequent treatments on diseases that affect the natives. This article discusses Malay traditional medicine based on selected Malay manuscripts, including that of medicinal and historical accounts that included medical services by Malay medical practitioners. Aspects that will be focused upon are historical account of Malay medicines pre- and post-Islam, medical services by Malay medical practitioners, types of diseases, medicines and methods of treatment in treating diseases.
\end{abstract}

\section{Pengenalan}

Setiap manusia di dunia akan merasai kesihatan yang baik dan keuzuran yang tidak dapat dielakkan dalam kehidupannya. Semuanya adalah bergantung kepada keseimbangan tubuh badan seseorang manusia. Terdapat beberapa faktor keuzuran dalam kepercayaan masyarakat Melayu iaitu disebabkan oleh penyakit tua, sihir, alam sekitar dan kuasa luar biasa (hantu, polong, pelesit). Oleh kerana keuzuran tersebut, masyarakat Melayu telah cuba mencari cara atau kaedah untuk merawatnya dengan merujuk kepada pakar perubatan tradisional seperti para sami, pendeta dan bomoh. 
Khidmat pengamal perubatan tradisional ini telah digunakan oleh masyarakat sejak sebelum kedatangan Islam lagi. Walaupun telah lama wujud, namun amalan perubatan ini sukar dikenalpasti dari segi kaedah dan rawatan yang dipraktikkan rentetan tiada manuskrip perubatan sebelum kedatangan Islam yang masih kekal sehingga ke hari ini. Kebanyakan manuskrip Melayu yang wujud sehingga hari ini adalah manuskrip yang dihasilkan selepas kedatangan Islam. Walau bagaimanpun kedudukan perubatan tradisional ini masih boleh dikategorikan sebagai tidak saintifik dan sesetengahnya bercanggah dengan prinsip perubatan Islam masa kini kerana terdapat hubungan antara kuasa ghaib dan perubatan Melayu.

Kajian mengenai perubatan Melayu pernah dilakukan oleh beberapa pengkaji barat yang berada di rantau ini seperti Skeat, Gimlette, Winstedt, Wilkinson, Wilder dan Endicott. Bagi mereka perubatan Melayu mempunyai pengaruh yang kuat dengan kepercayaan magis dan makhluk ghaib. Ini berlaku disebabkan oleh pengaruh daripada kepercayaan animisme, diikuti oleh unsur-unsur Hindu dan akhir sekali ialah unsur Islam. Berdasarkan kajian mereka, pengaruh Shamanisme adalah inti dalam amalan dan falsafah perubatan Melayu dan pengaruh lain seperti Islam hanyalah lapisan tipis di luar dari Shamanisme ini. Walau bagaimanapun kajian mereka banyak merujuk kepada sumber lisan dan pengalaman peribadi dengan para pengamal perubatan Melayu sahaja dan kurang menggunakan manuskrip Melayu yang terdapat di rantau ini.

\section{Perubatan Era Sebelum dan Selepas Kedatangan Islam}

Sebelum kedatangan Islam ke rantau Alam Melayu khususnya di Tanah Melayu, masyarakat Melayu telah lama mempunyai cara perubatan tradisional. Mereka juga mengetahui sejak zaman berzaman khasiat tumbuh-tumbuhan yang terdapat di kediaman mereka. Memandangkan alam semulajadi di rantau ini yang penuh dengan tumbuhan herba menyebabkan masyarakat kuno telah mempunyai cara tersendiri dalam mengubati penyakit-penyakit yang wujud ketika itu. Selain itu, mereka juga turut menggunakan akar-akar kayu ${ }^{1}$ selain benda-benda hidup ${ }^{2}$ (bernyawa) dan juga yang tidak bernyawa ${ }^{3}$ dalam perubatan Melayu. Tumbuh-tumbuhan yang digunakan dalam perubatan ini diberikan nama khas dan berbeza antara satu sama lain. ${ }^{4}$

Secara umumnya konsep perubatan Melayu pra Islam banyak memasukkan unsur mitos dan kepercayaan menurut agama atau kepercayaan masing-masing. Kepercayaan masyarakat Melayu pra Islam boleh dikatakan lebih tertumpu kepada semangat atau roh yang dikaitkan dengan kepercayaan animisme. ${ }^{5}$ Kesan daripada fahaman 
animisme ini, lahir kepercayaan dinamisme iaitu kepercayaan kepada tenaga. Tenaga tersebut wujud dalam roh, jiwa dan semangat diri manusia, haiwan, tumbuh-tumbuhan selain benda-benda yang boleh mendapat kesan baik dan buruk kepada manusia. ${ }^{6}$

Pelbagai upacara dilakukan bagi tujuan berkomunikasi dengan kuasa ghaib ini iaitu melalui upacara 'menyembah pantai' atau 'memberi makan hantu'. ${ }^{7}$ Kuasa-kuasa ghaib atau luar biasa diseru, dihormati dan dijaga kerana dikhuatiri boleh membawa kemudaratan kepada masyarakat yang tidak menghormatinya sehingga menyebabkan mereka mendapat keuzuran atau penyakit atau kesusahan atau bala. ${ }^{8}$ Dalam usaha mengubat penyakit yang menimpa mereka, biasanya khidmat bomoh, ${ }^{9}$ dukun, ${ }^{10}$ pawang ${ }^{11}$ atau bidan akan digunakan kerana mereka dianggap sebagai individu yang berkemampuan untuk berhubung dengan kuasa ghaib ketika melakukan pengubatan. Malah ketika ini institusi perbomohan menjadi penting dalam masyarakat sehingga terdapat gelaran bomoh diraja yang dikhaskan merawat golongan diraja. ${ }^{12}$

Di samping itu, pengaruh agama Hindu-Buddha terhadap perubatan tradisional Melayu memberi kesan mendalam kepada masyarakat rantau ini terutama cara berfikir dan bertindak di samping kewujudan pengaruh animisme yang masih menebal. Memandangkan ajaran Hinduisme-Buddhisme mempunyai ciri-ciri animismedinamisme, masyarakat Melayu awal merasakan kepercayaan yang baru dibawa masuk serasi dan tidak bertentangan dengan kepercayaan sedia ada yang mereka anuti. ${ }^{13}$ Melalui gabungan kepercayaan ini maka terdapat pelbagai upacara dan adat istiadat Melayu yang melibatkan makhluk halus selain ungkapan jampi, ${ }^{14}$ mantera ${ }^{15}$ dan serapah ${ }^{16}$ yang menjadi sandaran kepada pawang, bomoh dan dukun. Jampi, mantera dan serapah yang mempengaruhi pemikiran awal pengamal perubatan ini telah diperturunkan dari satu generasi ke satu generasi yang lain. Apa yang diperoleh oleh generasi berikutnya digunakan oleh mereka untuk mengubat pesakit-pesakit seterusnya.

It is generally recognized and accepted by Malay villager that the knowledge of spells, charms and incantations which bomor possesses is not of his own making, but an inheritance of the accumulated wisdom of the past. ${ }^{17}$

Kedatangan Islam yang dibawa oleh ulama dan pedagang dari Arab dan India ke rantau Alam Melayu telah menyebabkan berlakunya pertembungan budaya termasuk pertukaran ilmu pengetahuan tentang perubatan mereka. Agama Islam telah berasimilasi dengan budaya tempatan dan mempengaruhi amalan perubatan dan perawatan tradisional Melayu. Ini dapat dilihat melalui istilah-istilah, kaedah 
rawatan, jenis-jenis ubat, azimat dan sebagainya yang yang dibawa daripada negara mereka lalu diajarkan kepada masyarakat tempatan. ${ }^{18}$ Selain itu, ilmu perubatan Melayu yang ditulis adalah menggunakan tulisan jawi dengan memasukkan unsur-unsur keislaman seperti beberapa potong ayat al-Quran di dalamnya selain puji-pujian kepada Allah, selawat ke atas Nabi Muhammad s.a.w dan sebagainya.

Pertembungan dan pertukaran budaya dalam bidang ini telah menyebabkan lahirnya istilah-istilah baru dalam ilmu perubatan Melayu seperti tabib (doktor atau pengamal perubatan), tib (ubat) dan mujarabat (mujarab) yang berasal daripada perkataan Arab. Kelihatan banyak karya atau manuskrip perubatan Melayu yang dikarang oleh para pengarang atau pengamal perubatan tempatan menggunakan istilah tersebut sebagai judul karangan mereka seperti istilah Tib, tabib, ubat, mujarabat. Kitab Tib, Tabib atau Mujarabat ini mengandungi sekurang-kurangnya tentang jenis-jenis penyakit, ubat dan cara rawatan yang digunakan oleh para pengamal perubatan tradisional suatu ketika dahulu.

Istilah kitab Tib atau tibb bermaksud 'kitab ubat', 'kitab perubatan' atau 'ilmu perubatan'. Kandungan kitab tib Melayu tidak terbatas kepada ilmu perubatan dan pengubatan penyakit semata- mata tetapi juga mencakupi ilmu-ilmu lain seperti ilmu bintang dan ramalan, ilmu firasat, ta'bir mimpi dan sebagainya. ${ }^{19}$ Jika dilihat menerusi manuskrip perubatan Melayu kebanyakannya menerangkan tentang jenis penyakit, cara rawatan atau ubat yang digunakan ketika merawat pesakit tanpa menerangkan takrifan ilmu tib. Namun jika dilihat menerusi bab ketujuh naskhah Bustan Al-Salatin MSS 1076 Nuruddin al-Raniri, ${ }^{20}$ penerangan tentang ilmu tibb dan khidmat tabib dibincangkan dengan agak mendalam berbanding naskhah-naskhah lain. ${ }^{21}$ Sheikh Nuruddin alRaniri yang mengambil takrifan ilmu tibb daripada beberapa tabib lain memberikan takrifan tentang ilmu tersebut sebagai 'pengetahuan akan ehwal badan insan dan memelihara sihat tubuh lagi menyembuhkan segala penyakit daripada segala wujud". ${ }^{22}$ Adalah dipercayai takrifan ini diperoleh daripada buku Qanun fi al-Tibb karangan tokoh perubatan Islam terkenal iaitu Ibn Sina. ${ }^{23}$ Bagi Nuruddin ilmu tibb adalah suatu ilmu yang amat penting dan mempunyai faedah yang besar serta dianggap ilmu kedua terpenting selepas ilmu agama oleh Nabi Muhammad s.a.w kerana aspek kesihatan berkait rapat dengan diri manusia. ${ }^{24}$

\section{Khidmat Pengamal Perubatan Tradisional}

Perkhidmatan pengamal perubatan tradisional sering digunakan oleh masyarakat Melayu sejak dahulukala lagi. Seseorang yang ingin 
menjadi pengamal perubatan atau yang akan merawat seseorang pesakit seperti tabib, bomoh, pawang dan dukun perlu mempelajari ilmu-ilmu perubatan atau pertabiban. Namun kebanyakan manuskrip perubatan Melayu tidak membincangkan tentang ilmu pertabiban atau syarat bagi yang ingin menjadi seorang pengamal perubatan melainkan beberapa buah manuskrip yang dikenalpasti.

Setakat ini, penerangan tentang ilmu pertabiban secara mendalam dapat dilihat menerusi manuskrip Kitab Tib MSS 2515 (PNM), Kitab Ilmu Tabib (DBP), Kitab Tib 1714 (DBP) dan Cod. Or 1714 Kitab Tib ( Leiden) terutama di bahagian awal kitab-kitab tersebut sebelum membincangkan jenis-jenis penyakit, kaedah rawatan dan ubat-ubatan yang digunakan. ${ }^{25}$ Antara ilmu perubatan yang dipaparkan dalam semua manuskrip abad ke-19 ini adalah mengenai pengenalan ilmu tabib iaitu ilmu yang seharusnya diketahui oleh seseorang pengamal perubatan seperti ilmu ramalan atau astrologi, astronomi, rejang, raksi dan sebagainya termasuk petua supaya mereka tidak terkena penyakit ketika atau selepas merawat pesakit sebelum mereka menerima tugas merawat seseorang pesakit. ${ }^{26}$

Di samping itu, para pengamal perubatan juga perlu mengetahui dan memahami semua aspek berkaitan perubatan Melayu seperti konsep tubuh badan manusia, kepentingan perubatan Melayu dan cara pembedahan dalam ilmu perubatan tradisional secara lebih mendalam. Aspek ini dapat dilihat melalui kitab tib, fasal 3 bab 7 Bustan al-Salatin, karangan Nuruddin al-Raniri yang membincangkan tentang konsep tubuh badan manusia yang dikaitkan dengan tabiat, perangai, perkataan, perbuatan dan pekerjaannya. ${ }^{27}$ Nuruddin turut memasukkan beberapa keterangan mengenai keharusan berubat bagi seseorang yang berpenyakit kerana setiap sesuatu penyakit yang dijadikan itu ada penawar atau penyembuhan baginya. ${ }^{28}$ Di samping itu, turut dinyatakan larangan berubat menggunakan benda-benda haram atau menyalahi daripada landasan agama selain larangan memakan makanan yang mempunyai unsur yang sama seperti panas kedua-duanya atau sejuk kedua-duanya, kering kedua-duanya atau basah kedua-duanya kerana boleh mendatangkan kemudharatan bagi tubuh manusia. ${ }^{29}$

Biasanya khidmat pengamal perubatan ini diperlukan jika seseorang itu mengalami atau diserang sesuatu penyakit. Setakat kajian, didapati manuskrip perubatan Melayu tidak menyebut golongan manakah yang dirawat oleh para pengamal perubatan. Jika dilihat menerusi beberapa buah karya pensejarahan Melayu, khidmat pengamal perubatan tradisional digunakan dalam merawat penyakit yang dialami oleh masyarakat tempatan terutamanya golongan diraja. 
Beberapa istilah yang digunakan bagi merujuk kepada pengamal perubatan tradisional iaitu tabib, pawang, bomoh dan dukun.

Menerusi Sulalat al-Salatin kelihatan khidmat tabib telah digunakan sejak zaman kesultanan Melayu Melaka. Ini dapat dilihat dalam kisah raja China telah mendapat penyakit gatal-gatal di seluruh badan dan menjadi kedal setelah mengirim sembah kepada Sultan Mansur Shah. Ratusan tabib telah dititahkan untuk merawat penyakit baginda tetapi tidak sembuh. Lalu seorang tabib tua memberi sembah kepada raja China supaya mendapatkan air basuhan kaki Sultan Mansur Shah. Setelah mendapat air basuhan kaki Sultan Melaka, maka sembuhlah penyakit gatal dan kedal yang dialami oleh raja China. ${ }^{30}$

Selain itu, khidmat tabib juga digunakan ketika Tun Hamzah terkena luka akibat diparang oleh seorang Benggali bernama Mia Sima. Begitu juga khidmat tabib digunakan ketika Seri Udani mendapat luka di ari-arinya akibat terkena tombak semasa Portugis menyerang Melaka. Sultan Ahmad telah memerintahkan tabib untuk merawat Seri Udani. Tabib tersebut telah menggunakan ekor sirih untuk mengubatnya dan dengan izin Allah, Seri Udani pun pulih seperti sediakala dan dapat berjuang menentang Portugis walaupun terkorban akhirnya. ${ }^{31}$

Misa Melayu juga turut menyebut khidmat tabib digunakan semasa Sultan Muzaffar Shah, Perak (1728-1756) mengalami kegeringan. Beberapa orang tabib telah dititahkan mengubati penyakit baginda dengan menggunakan ubat-ubatan yang dibuat oleh mereka sendiri. Begitu juga semasa Sultan Iskandar Shah (1756-1770) mengalami beberapa kali kegeringan, tabib lelaki dan perempuan selain khidmat daripada tukang tilik dititahkan bagi mengubati penyakit baginda. Para tabib ini dikatakan menggunakan pelbagai jenis ubat-ubatan yang dibuat menggunakan pengetahuan mereka sendiri selain bertilik, berzikir, berdoa dan menggunakan khidmat jin. Dengan pertolongan Allah dan kemujaraban ubat-ubatan yang disediakan ini, Sultan Iskandar Shah dikatakan telah sembuh daripada penyakit tersebut. ${ }^{32}$

Dalam naskhah Riwayat Kelantan pula, Seri Maharaja Siam juga menggunakan khidmat tabib. Ini dapat dilihat apabila baginda menitahkan semua tabib di benua Siam untuk mengubati penyakit kedal baginda. Memandangkan penyakit kedal tidak berjaya diubati, baginda telah memanggil seorang alim Siam atau Chai untuk mengubatinya. Chai memberitahu bahawa tiada ubat yang dapat menyembuhkan penyakit baginda selagi Puteri Saadung berada di Siam dan tidak dibebaskan. Oleh yang demikian, Puteri Saadung telah dibenarkan kembali ke negeri Kelantan dan selang beberapa hari penyakit Maharaja Siam itu pun sembuh seperti sediakala. ${ }^{33}$

Walaupun khidmat tabib telah digunakan ketika itu, namun masyarakat Melayu turut gemar menggunakan khidmat bomoh atau 
dukun atau pawang. Kedudukan atau status seseorang bomoh cukup berpengaruh dalam masyarakat Melayu. Bomoh merupakan orang yang terpenting dan paling atas kedudukannya dalam masyarakat Melayu sehingga anggota masyarakat setempat menumpukan kepercayaan, tempat berlindung daripada segala bencana dan tempat meminta pertolongan, bukan sahaja untuk menyembuhkan penyakit bahkan segala aspek kehidupan orang ramai. ${ }^{34}$ Misalnya dalam Sulalat alSalatin, khidmat bomor (bomoh) turut digunakan dalam hal menjerat gajah pada zaman pemerintahan Sultan Abdul Jamal, Pahang. ${ }^{35}$ Begitu juga Hikayat Abdullah turut menyebut tentang hal menangkap gajah di Sebatu menggunakan khidmat Pawang Gajah. Pawang ini dipercayai oleh masyarakat bukan sahaja mahir dalam ilmu gajah tetapi juga dalam urusan ubat-ubatan dan membuat tangkal. ${ }^{36}$ Sulalat al-Salatin turut menyebut tentang khidmat pawang iaitu Cedun Pawang Antan yang digunakan ketika mencukur kepala seorang kanak-kanak selain pawang juga dianggap sebagai ketua kepada nelayan. ${ }^{37}$ Kelihatan khidmat pawang atau bomoh (bomor) tidak hanya tertakluk dalam urusan mengubati penyakit yang dialami manusia tetapi turut digunakan dalam menjerat gajah dan sebagainya.

Selain itu, khidmat dukun turut disebut dalam Tuhfat al-Nafis terutama dalam mengubat atau merawat penyakit golongan diraja. Misalnya ketika Raja Di Baruh, putera Sultan Sulaiman Johor sampai di Selangor, beliau telah mendapat penyakit demam lalu beberapa orang dukun telah dititahkan oleh Yang Di Pertuan Selangor (Raja Lumu) untuk mengubati beliau. Begitu juga ketika Sultan Sulaiman gering, beberapa orang dukun dan tabib telah dikumpulkan oleh Datuk Bendahara untuk mengubati baginda itu. Namun penyakit baginda tidak juga sembuh sehingga membawa kemangkatan baginda pada 1761.38

Hal yang sama turut berlaku dalam kesultanan Siak iaitu ketika Yang Dipertuan Raja Ismail mendapat gering dan segala dukun telah dikumpulkan untuk mengubati penyakit baginda. Namun penyakit baginda semakin bertambah berat sehingga membawa kepada kemangkatan baginda. Khidmat dukun juga digunakan ketika ini dalam hal mengubat penyakit gila yang dihadapi oleh Yang Dipertuan Muhammad Ali, Siak. Akhirnya penyakit gila baginda ini telah dapat diubati oleh dukun tersebut selain bantuan oleh beberapa tuan Syed (dipercayai syeikh/tabib) sehingga penyakit baginda sembuh seperti sediakala. ${ }^{39}$ Khidmat tuan syed atau syeikh ini turut digunakan oleh Raja Phaya Tu Naqpa ketika baginda menghidapi penyakit yang sukar diubati oleh semua tabib di Patani. Tuan syed memberi syarat supaya baginda memeluk Islam setelah sembuh daripada penyakit. Namun setelah sembuh, baginda tidak menunaikan janji lalu penyakit tersebut 
berulang kembali. Setelah tiga kali hal yang sama berlaku, barulah baginda benar-benar memeluk Islam dengan gelaran Sultan Ismail Shah Zillullah fil Alam. ${ }^{40}$

Jelas naskhah-naskhah ini menunjukkan bahawa khidmat tabib, bomoh, pawang diperlukan dalam merawat penyakit yang dihidapi oleh masyarakat sama ada golongan diraja mahupun rakyat biasa. Rawatan yang diberikan oleh mereka ini adalah dalam semua urusan berkait dengan kesihatan seperti merawat luka, penyakit demam, kedal, gila dan sebagainya termasuk urusan menjinakkan binatang. Walaupun secara umumnya mereka mempunyai tugas khas dengan gelaran yang diberikan, namun rata-rata masyarakat menganggap tugas mereka tidak banyak berbeza antara satu sama lain ketika itu. Jika khidmat mereka diperlukan terutama merawat golongan diraja, mereka bersedia membantu dalam apa jua keadaan sekalipun. Ini kerana masyarakat merasakan bahawa mereka adalah pakar dalam hal tersebut dan diletakkan pada kedudukan tertinggi dalam masyarakat. Kedudukan mereka ini telah diangkat oleh golongan istana sehingga terdapat peruntukan dalam Undang-Undang Sembilan Puluh Sembilan Negeri Perak yang bukan sahaja menggariskan tugas-tugas pawang tetapi pemerintah tidak boleh mengenakan hukuman kerah atau kerja paksa selain perlu membayar saguhati kepada pawang atau bomoh diraja. ${ }^{41}$

"Jika membela kampung sepaha emas upahnya, barang yang lebih itu pulang kepada pawang, jika membela galian dengan hantu, pawang itu upahnya sepaha emas, barang yang lebih itu pulang kepada pawang dan salinan pawang itu dengan baju tengkoloknya hitam. $^{42}$

Menurut R. J. Wilkinson, kedudukan bomoh dalam masyarakat Melayu disifatkan oleh beliau sebagai berikut:

In the Malay state of Perak the sorcerer or pawang was a man of good repute a paid servant of the government, whose business was to heal the sick, direct the planters, watchover the mines and give expert advice to fisherman. He was in short the most important person in his village. ${ }^{43}$

Terdapat banyak lagi karya pensejarahan yang menerangkan tentang khidmat pengamal perubatan ini semasa golongan diraja mendapat penyakit gering dan sebagainya. Walau bagaimanapun kesemua naskhah ini hanya menerangkan secara umum atau sepintas lalu sahaja tentang khidmat yang diberikan tanpa penjelasan lanjut tentang caracara rawatan yang dilakukan atau jenis ubat yang diberikan kepada pesakit. Memandangkan karya-karya sejarah tidak menerangkan tentang rawatan dan jenis penyakit yang dihidapi oleh golongan diraja, 
maka jenis-jenis penyakit, cara-cara rawatan dan jenis-jenis ubat yang digunakan pada zaman silam perlu dirujuk menerusi naskhah atau manuskrip khusus berupa Kitab Tib, Kitab Ubat atau Mujarabat atau Kitab Petua Melayu dan sebagainya yang telah dihasilkan oleh para pengamal perubatan.

Kitab-kitab ini boleh diperoleh di beberapa lokasi penyimpanan manuskrip Melayu tradisional di pelbagai tempat di dalam mahupun di luar negara. Selain Perpustakaan Universiti Leiden yang banyak menyimpan koleksi manuskrip perubatan Melayu, Perpustakaan Negara Malaysia juga tidak kurang banyaknya selain terdapat di Perpustakaan Dewan Bahasa dan Pustaka, ${ }^{44}$ Perpustakaan pelbagai IPTA, dan sesetengah arkib dan muzium negeri. Jumlah manuskrip perubatan Melayu yang banyak ini membuktikan bahawa masyarakat Melayu terutama kalangan pengamal perubatan telah mempunyai kesedaran untuk mencatatkan tentang jenis-jenis penyakit dan ubatubatan yang digunakan selain kaedah rawatan yang diberikan kepada pesakit.

\section{Penyakit, Kaedah Rawatan dan Jenis Ubat Tradisional}

Jika dilihat menerusi beberapa buah manuskrip perubatan Melayu terdapat begitu banyak jenis penyakit dan kaedah rawatan yang dipaparkan oleh pengarang atau pengamal perubatan tersebut. Sesetengah manuskrip membincangkan dengan panjang lebar tentang sesuatu penyakit itu, manakala sesetengahnya pula hanya membincangkan secara ringkas dan umum sahaja. Antara penyakit yang sering disebut dalam semua manuskrip Melayu ialah penyakit demam, batuk, balgham dan sebagainya.

Jika dilihat menerusi Kitab Tib MSS 2515, penyakit demam khususnya kepialu dibincangkan dengan panjang lebar sebanyak 62 halaman. Selain itu, turut dinyatakan kaedah mengenal penyakit demam kepialu, pembahagian kategori atau jenis deman kepialu seperti demam kepialu kedalaman, deman kepialu angin, demam kepialu terkena, kepialu besar atau gila dan sebagainya. ${ }^{45}$ Terdapat juga pelbagai cara rawatan dan jenis ubat-ubatan yang boleh menyembuhkan penyakit kepialu yang dipaparkan dalam manuskrip tersebut. ${ }^{46}$ Antara kaedah rawatan demam kepialu yang dicatatkan seperti berikut:

Bab ini fasal pada menyatakan ubat mandi orang demam kepialu maka ambil akar belalai pok dan akar menjarum gajah dan akar ketola dan akar tebu gajah dan akar menterajam dan bunga tampam, maka semuanya itu cincang lumat-lumat maka tumbuk, sudah itu maka rendamkan pada pasu maka kita mandikan, beri sejuk hingga deras air bawah rumahnya, afiat. ${ }^{47}$ 
Selain itu, pengarang kitab ini tidak ketinggalan juga mencatatkan beberapa penyakit lain yang bersangkutan dengan demam kepialu seperti batuk dan sakit medu (rasa loya, sakit hulu hati, ngilu hati dan sebagainya). Semua penyakit ini dicatatkan juga kaedah rawatan dan ubat-ubatan yang sesuai dan boleh digunakan oleh masyarakat tempatan. ${ }^{48}$

Begitu juga jika dilihat menerusi Cod. Or. 1714 Kitab Tib dan Ilmu Tabib, penyakit demam dibahagikan kepada beberapa jenis demam seperti demam kepialu, demam kura dan demam panas yang dibincangkan dengan panjang lebar. ${ }^{49}$ Selain itu, cara rawatan khusus dan kepelbagaian ubat yang disarankan bagi setiap penyakit turut dinyatakan dengan jelas dan menarik. Ubat-ubat yang digunakan adalah daripada tumbuh-tumbuhan dan akar kayu misalnya dalam mengubat penyakit demam panas:

Fasal ini pada menyatakan ubat demam panas di luar dan di dalam, dan pada dahi dan tubuhnya. Maka (akan ubatnya:) Ambil gelang sambar dara \{dan\} setawar \{dan\} pucuk lancung \{dan\} pucuk birah \{dan\} adas manis \{pula sedikit dan\} (bunga) pulasari \{dan\} putik bira (bebaru yang) dibembam \{dan\} bawang putih \{dan\} bawang merah (mesui) dan pinang muda yang belum bertemu hatinya. (Semuanya itu) pipis lumat-lumat $\{$ maka\} (beri) minum $\{$ kan dan setengah $\}$ (lagi) jelumkan pada tubuhnya, \{nescaya (insyaAllah) afiat. ${ }^{50}$

Selain itu terdapat juga rawatan menggunakan tangkal atau azimat yang dipaparkan dalam Cod Or 1714 Kitab Tib iaitu dengan menggunakan daun dedap berserta kulitnya dan batang sudu-sudu dengan pucuknya. Kemudian semuanya dipipis dengan cuka dan dibedakkan pada pesakit. Dibelikat kiri dan kanan pesakit perlu dituliskan huruf sebagai tangkal atau azimat. ${ }^{51}$

Di samping itu, terdapat beberapa penyakit lain yang dibincangkan dengan mendalam iaitu penyakit balgham (lendir atau kahak) yang mempunyai beberapa kategori. Jika dilihat menerusi Kitab Tib MSS 2515, kaedah mengubat penyakit balgham termasuk batuk, lelah dan esak dicatatkan sebanyak enam halaman. Pengamal perubatan juga tidak ketinggalan menyebut bahawa kaedah rawatan ini diperoleh daripada beberapa orang yang pakar dalam mengubat penyakit balgham. Misalnya daripada Haji Ahmad, Bilal Idris, Tuan Haji Farid dan Raja Singgora yang memberi maklumat tentang kaedah rawatan penyakit tersebut. ${ }^{52}$ Antara kaedah rawatan membuang balgham adalah seperti berikut: 
Ambil beras sejemput dan air limau nipis sebutir. Maka beras itu direndamkan pada air limau dan embunkan, pagi minum hendaklah/ diperbuat yang dahulu itu juga selagi keluar lendirnya lagi diperbuat. Dan tatkala hendak diperbuat ubat ini hendaklah minum santan nyiur hijau dengan air limau nipis, sama-sama sukat air yang kedua, nescaya lingkuplah balgham itu, mustajab. ${ }^{53}$

Manakala Cod. Or. 1714 Kitab Tib turut membicarakan tentang penyakit balgham dan batuk sebanyak tujuh halaman dan kitab Ilmu Tabib sebanyak empat halaman dengan menjelaskan jenis-jenis balgham sama ada yang basah mahupun kering. Terdapat beberapa jenis ubat yang digunakan untuk rawatan membuang balgham seperti rumput kepala lalat, rumput tahi babi, jintan hitam, kunyit, beras dan sebagainya. ${ }^{54}$ Menurut A. Samad Ahmad, sesetengah bomoh tidak mahu menyebut nama sesuatu bahan yang berkait dengan najis seperti rumput tahi babi untuk dijadikan sebagai ubat lalu mereka menukar namanya kepada "daun Lukman Hakim". 55

Penyakit demam mahupun balgham ini lebih banyak dipaparkan dengan penjenisannya menunjukkan bahawa penyakit ini sering dihidapi oleh masyarakat Melayu sehingga pengamal perubatan berupaya mengkelaskannya. Selain itu, tercatat juga beberapa penyakit lain yang biasa dihidapi oleh masyarakat seperti penyakit sembelit, pitam, sakit mata dan telinga, restung atau resdung dan penyakit karang yang tercatat dalam Kitab Tib MSS 2515, Cod. Or. 1714 Kitab Tib dan Kitab Ilmu Tabib. ${ }^{56}$

Selain itu, para pengamal perubatan turut mempunyai pengetahuan dalam merawat patah tulang, tergeliat urat saraf atau menawar racun dan sebagainya. ${ }^{57}$ Pengarang Kitab Ilmu Tabib yang merujuk kepada kata-kata Lukmanul Hakim menyebut bahawa apabila seseorang terkena bencana atau termakan racun, mereka harus menulis ayat di bawah ini pada tapak tangan dan kemudian dijilat tulisan tersebut dengan lidah sebanyak tujuh kali. Ketika menulis ayat ini, mereka hendaklah dalam keadaan berwuduk dan berkain suci. Ayatnya adalah seperti berikut:

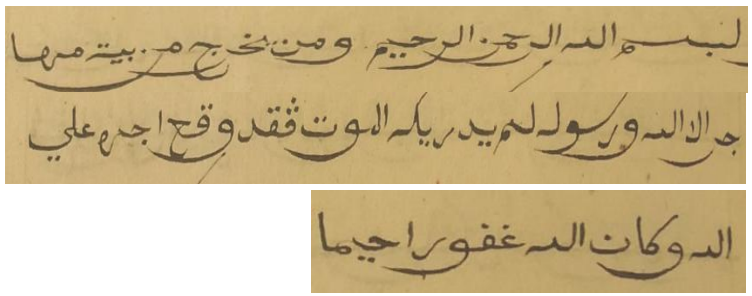

Sumber: Cod. Or. 1714 Kitab Tib (jawi), Perpustakaan Universiti Leiden, Netherlands hlm. 217 (koleksi peribadi). Lihat juga A. Samad Ahmad, Warisan Perubatan Melayu, KL: DBP, 1982, hlm.113 
Kepelbagaian penyakit dengan rawatan yang dipaparkan ini menunjukkan bahawa orang Melayu telah mahir dan berpengetahuan dalam mengklasifikasikan penyakit dan rawatannya. Kelihatan setiap penyakit yang dipaparkan ini bukan mempunyai hanya satu jenis rawatan dan satu jenis ubat sahaja malahan pelbagai rawatan dan jenis ubat yang digunakan oleh mereka. Ini menunjukkan bahawa pengamal perubatan berpengetahuan luas dalam ilmu perubatan dan mempunyai cara tersendiri dalam merawat penyakit. Mereka juga menggunakan pelbagai jenis ubat yang dibancuh sendiri berdasarkan pengetahuan yang peroleh daripada pakar tertentu atau ilmu yang diperturunkan dari satu generasi ke satu generasi yang lain.

\section{Mantera, Jampi Serapah dan Azimat Dalam Rawatan}

Selain ubat-ubatan yang digunakan, para pengamal perubatan tidak ketinggalan membaca beberapa potong ayat al-Quran, jampi atau mantera selain membuat azimat atau tangkal bagi sesuatu penyakit yang dirawatnya. Walaupun terdapat sedikit perubahan dalam kaedah rawatan mereka iaitu memberi nafas keislaman berpandukan al-Quran dan hadis, namun beberapa aspek perubatan pra Islam seperti mantera, jampi dan serapah yang diamalkan dalam perubatan pra Islam masih terus digunakan oleh para bomoh, pawang atau dukun yang mengubati pesakit.

Jampi atau mantera biasanya dilakukan oleh para pengamal perubatan bagi menguatkan semangat pesakit dan keupayaan ramuan ubat itu untuk bertindak. Terdapat beberapa rangkai kata yang digunakan dalam memohon pertolongan daripada pihak-pihak tertentu. Kelihatan dalam jampi tersebut dimasukkan sebutan nama Allah dan Nabi Muhammad SAW, manakala sesetengahnya mengaitkan dengan makhluk-makhluk lain. Bagi menambahkan lagi keberkesanan, lafaz jampi atau mentera akan dimulakan dengan 'Bismillah hir rahmanir rahim' dan diakhiri dengan lafaz kalimah 'La ilaha ila Allah, Muhammadu Rasulullah. ${ }^{58}$ Di samping itu, terdapat juga sebutan salam, nama-nama Allah berserta sifat-sifat-Nya, nama rasul dan nabi, nama panglima Islam atau nama-nama lain yang menunjukkan berlakunya pengaruh Islam. Tidak terkecuali juga unsur-unsur animisme dan kehinduan yang tidak diketahui makna atau yang sukar ditafsirkan maksudnya turut dimasukkan. ${ }^{59}$ Antara mantera yang bercampur dengan unsur keislaman dalam rawatan demam kepialu adalah seperti berikut:

...demikian manteranya tatkala mengambil daun kerak nasi itu, inilah kata-katanya:

Assalamu alaikum ibuku bumi, 
Aku hendak minta ubat medu

(Jika yang sakit itu laki-laki kita kata ubat akan umat Ali

Jika yang sakit itu perempuan kita kata aku minta ubat akan umi Fatimah)

Walaikum salam. ${ }^{60}$

Selain itu, dicatatkan juga dalam Cod. Or 1714 Kitab Tib dan Ilmu Tabib tentang penggunaan mantera bagi menawarkan segala racun yang dibacakan pada air nyiur atau air benar iaitu:

Sidang Gha sii \{raja\} (sidang nasi) tapak (raha) burnii \{kolo\} (kolam) raja burni \{membawak\} (sembawak) tawar sepanjang sungai Tawar sekalian wujud tawar sekalian alam tawar sekalian bisa tawar Allah tawar Muhammad tawar baginda Rasulullah (s.a.w) (nescaya tawar racun itu). ${ }^{61}$

Selain itu mantera juga digunakan dalam masalah patah tulang dan tergeliat urat saraf adalah seperti berikut:

Inilah mantera patah batu hubung batu, (patah) urat \{putus\} hubung urat, (patah tulang hubung tulang) \{yang tulang hubung\}, patah sendi hubung sendi, siap rapat maha rapat, dengan berkat Lailaha ilallah Muhammada Rasulullah...Hong sam sam, \{berhubung samsam\} bertemu urat (dengan daging) (bertemu urat dengan) sendi \{tupat\} (tumbuh tempat) pulang \{puk\} (pulih) seperti \{doa dat dahulukala \} (adat sediakala dengan) berkat (kalimah) Lailaha ila Allah Muhammad Rasulullah. ${ }^{62}$

Mantera dan jampi serapah mula diserap dan dicampurkan dengan doa, beberapa potong ayat suci al-Quran dan selawat. Kelihatan seseorang pengamal perubatan yang merawat pesakit akan sedaya upaya 'mengislamkan' amalan perubatan mereka supaya kelihatan pada zahirnya tidak bertentangan dengan ajaran Islam. ${ }^{63}$ Walau bagaimanapun, teras pencorakan rawatan baru ini dengan memasukkan unsur keislaman masih memasukkan unsur-unsur ghaib pra Islam seperti pemujaan semangat, roh-roh, makhluk-makhluk ghaib dan seumpamanya. ${ }^{64}$ Pengekalan aspek ini adalah kerana mereka beranggapan tidak lengkap proses perubatan tanpa adanya jampi, mantera atau serapah yang diselangi atau diakhiri dengan unsur keislaman seperti bacaan beberapa potong ayat-ayat al-Quran atau doa atau nama ahli al-Bait, nama Nabi Muhammad s.a.w atau kalimah syahdah, bacaan salam dan sebagainya. Walaupun demikian, terdapat juga golongan yang berpegang teguh kepada ajaran Islam tidak mudah menerima cara perubatan tersebut tetapi cuba mengikut lunas-lunas Islam sebenar. ${ }^{65}$ 
Selain mantera dan jampi serapah, tangkal dan azimat yang dikenali juga sebagai wahinah dan wafaq juga disediakan oleh para pengamal perubatan untuk dipakai atau digunakan oleh masyarakat yang mempercayainya. ${ }^{66}$ Menurut Abdul Razak Abdul Karim, “Wafaq merupakan penggunaan huruf-huruf ataupun angka-angka dalam tulisan Arab yang dipercayai dapat memberi perlindungan ataupun sebagainya bergantung pada jenis wafaq yang digunakan" ${ }^{67}$ Sesetengah wafaq dilukis dalam bentuk simbol, gambarajah, nombor yang memberi maksud tertentu seperti pengasihan, kekuatan, kebatinan dan sebagainya. Antara wafaq yang biasa digunakan adalah untuk sakit kepala, perempuan yang mandul, pengasih perempuan, memudahkan orang beranak, sawan kanak-kanak dan sebagainya. ${ }^{68}$
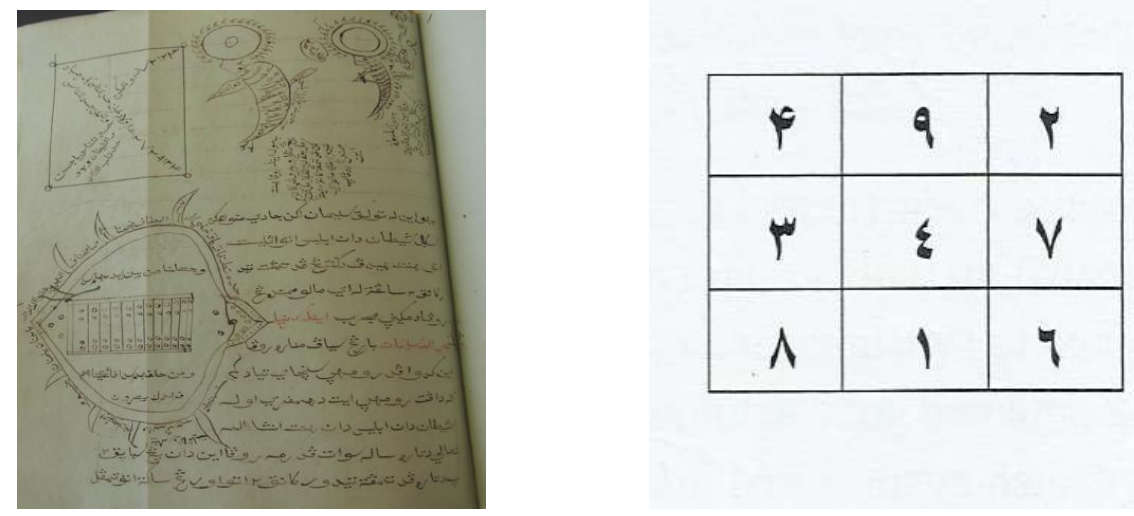

Sumber : Cod. Or. 1714 Kitab Tib (jawi), Perpustakaan Universiti Leiden, Netherlands, hlm. 434. (koleksi peribadi) (gambar kiri) dan Harun Mat Piah dan Zawiyah Baba, Kitab Tib MSS 2515 Perpustakaan Negara Malaysia: Kajian Teks dan Suntingan, Bangi: UKM, 2014, hlm. 85. (gambar kanan)
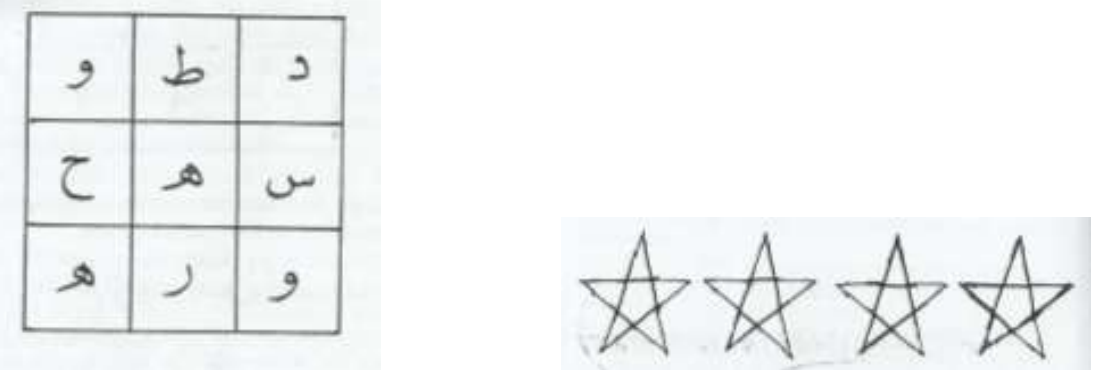

Sumber: Harun Mat Piah dan Zawiyah Baba, Kitab Tib MSS 2515 Perpustakaan Negara Malaysia: Kajian Teks dan Suntingan, Bangi: UKM, 2014, hlm. 60 dan 131. 
Wafaq digunakan oleh seseorang bagi menghindari dirinya daripada penyakit atau bencana dan lain-lain lagi. Walau bagaimanapun mereka perlulah mematuhi segala syarat yang telah ditetapkan ketika memakai atau menyediakannya. Jika mereka gagal mematuhi syaratsyarat tersebut, dikhuatiri wafaq ini tidak akan menjadi atau kurang keberkesanannya kepada pengguna tersebut. ${ }^{69}$

Jelas mantera, jampi serapah, tangkal atau azimat adalah kaedah rawatan yang digunakan oleh para pengamal perubatan tradisional Melayu sebagai usaha menyembuhkan penyakit yang dihidapi oleh seseorang pesakit. Keadaan ini menunjukkan bahawa unsur- unsur pra Islam masih wujud dalam rawatan tradisional Melayu walaupun unsur keislaman turut dimasukkan. Proses perubahan ke arah cara perubatan Islam sepenuhnya bukanlah suatu yang mudah tetapi mengambil masa yang agak panjang disebabkan oleh kepercayaan yang sudah 'mendarah daging' dalam diri masyarakat Melayu. Malah sehingga perubatan moden diperkenalkan pada awal ke-20, masyarakat Melayu masih menggunakan khidmat perubatan tradisonal yang turut mencampurkan cara rawatan pra Islam dengan unsur-unsur keislaman.

\section{Dari Perubatan Melayu Tradisional ke Perubatan Moden}

Pada akhir abad ke-19, konsep perubatan moden barat mula dibawa masuk ke Tanah Melayu oleh pihak British. Ketika ini dasar perubatan barat mula digubal dan dilaksanakan di Negeri-negeri Melayu Bersekutu bagi tujuan penyeragaman pentadbiran. Beberapa orang pegawai perubatan di peringkat persekutuan telah dilantik selain penubuhan jabatan perubatan. ${ }^{70}$ Terdapat juga beberapa buah hospital yang cemerlang dari segi perkhidmatan pakar bedah Inggeris dan dispensari disediakan oleh British. ${ }^{71}$ Namun, perubatan moden ini mendapat reaksi berbeza dalam kalangan masyarakat Melayu. Sesetengahnya menerima perubatan moden manakala sesetengah yang lain pula menentangnya. Mereka yang menolaknya bukanlah kerana aspek perubatan tersebut tetapi disebabkan oleh kesukaran untuk mengubah cara berfikir yang sudah sebati dengan pelbagai kepercayaan tradisi yang diamalkan sejak nenek moyang mereka. ${ }^{72}$ Mereka juga dibimbangi oleh perasaan bahawa perubatan barat adalah bertentangan dengan hukum Islam, makanan yang disediakan oleh kakitangan hospital kerajaan majoritinya bukan beragama Islam, ${ }^{73}$ selain secara tradisinya bergantung sepenuhnya kepada bomoh yang dianggap sebagai 'doktor' mereka. ${ }^{74}$ Oleh itu, masyarakat Melayu yang telah sebati dengan kaedah rawatan tradisional dilihat begitu sukar untuk menerima perkhidmatan perubatan yang diperkenalkan oleh pihak British. 
Beberapa akhbar memainan peranan dalam usaha memberi pencerahan tentang perubatan moden. Akhbar Saudara menyarankan agar masyarakat Melayu menolak kepercayaan mereka terhadap amalan perubatan tradisional berbentuk perbomohon. Akhbar ini juga cuba membuang tanggapan dan persepsi buruk terhadap perubatan barat dan menggalakkan mereka menggunakan perkhidmatan jururawat atau bidan terlatih. ${ }^{75}$ Selain itu, akhbar Bulan Melayu turut melaporkan keengganan masyarakat Melayu menerima perkhidmatan perubatan moden khususnya ibu-ibu mengandung dalam mendapatkan rawatan untuk melahirkan anak:

...pada kebanyakan kaum kita Melayu tiada mereka itu memakai doktor melainkan apabila telah bersalinnya itu payah atau apabila ada sesuatu apa kesilapan yang tok bidan itu tiada upaya membetulkannya ketika itu barulah mereka itu mencari bantuan doktor. ${ }^{76}$

Kebanyakan masyarakat Melayu terutamanya ibu mengandung lebih gemar mendapatkan khidmat bidan pada awal 1930-an. Implikasi penolakan rawatan hospital kerajaan menyebabkan berlaku kadar kematian bayi yang sangat tinggi di Tanah Melayu sekitar 1920-an akibat diserang oleh penyakit sawan. ${ }^{77}$ Walaupun demikian, hampir mustahil untuk mereka memujuk orang Melayu mendapatkan khidmat tersebut kecuali dalam kes-kes yang memerlukan rawatan pembedahan. ${ }^{78}$ Situasi ini telah menimbulkan masalah sehingga pihak British terpaksa mewajibkan masyarakat untuk mendapatkan rawatan. Misalnya rawatan vaksin yang telah diperuntukkan dalam undang-undang ketika itu. ${ }^{79}$ Walaupun masyarakat Melayu tidak menentang pelaksanaan vaksin dan menerimanya secara positif kerana sedar kepentingannya, namun bilangan mereka yang menerima rawatan tersebut adalah sedikit jika dibandingkan dengan kaum-kaum yang lain. ${ }^{80}$

\section{Kesimpulan}

Secara umumnya, ilmu perubatan Melayu tradisional boleh dilihat jelas menerusi manuskrip-manuskrip yang kebanyakannya boleh didapati di pelbagai lokasi. Banyaknya jumlah manuskrip yang berkait dengan perubatan ini memberi tafsiran bahawa ilmu perubatan adalah satu bidang yang sangat dominan dalam perbincangan masyarakat Melayu suatu ketika dahulu. Ilmu perubatan yang dipaparkan adalah penting bagi masyarakat ketika itu dalam mendapatkan rawatan pelbagai jenis penyakit. Ini menunjukkan bahawa masyarakat Melayu telah mempunyai kearifan dalam ilmu perubatan. Masyarakat juga percaya bahawa cara rawatan dan jenis ubat-ubatan yang dibekalkan oleh 
pengamal perubatan adalah mujarab atau berkesan sehingga diterima oleh masyarakat Melayu selama ratusan tahun. Oleh itu setiap kali mereka menghidapi sesuatu penyakit atau masalah kesihatan, mereka akan mendapatkan khidmat rawatan daripada pengamal perubatan tradisional sama ada di kawasan mereka atau tempat lain yang dirasakan boleh menyembuhkan sesuatu penyakit.

Kelihatan masyarakat Melayu tradisional tidak mengetepikan atau membuang keseluruhan kaedah perubatan Melayu pra Islam sebaliknya cuba mengadaptasi, mengintegrasi dan mempraktikkan amalan tersebut dengan amalan perubatan selepas kedatangan Islam ke rantau Alam Melayu. Walaupun manuskrip-manuskrip perubatan ini masih terdedah dengan pelbagai kritikan disebabkan oleh percampurannya dengan aspek pra Islam, namun sekurang-kurangnya manuskrip tersebut telah menyumbang ke arah proses perubatan dalam kalangan masyarakat Melayu.

\section{Nota}

1 Jenis-jenis tumbuhan herba adalah seperti tongkat Ali, Misai Ali, Janggut Ali, Kacip Fatimah (Labisa Fumila), Jarum Mas (Striga Asiatica) dan lainlain. Noor Eshah Tom Abdul Wahab dan Wan Aminah Haji Hasbullah, "Tumbuhan Herba dalam Masyarakat Melayu: Satu Tinjauan Awal dari Perpektif Kesihatan dan Ekosistem", Jurnal Manusia dan masyarakat, Jilid 19, 2010, hlm. 63.

2 Misalnya dalam perubatan tradisional, penggunaan anak tikus dipercayai dapat menyembuhkan sakit lelah dengan mengambil seekor anak tikus yang baru lahir dan dimasukkan ke dalam pisang dan ditelan bersamasama. Lintah pula digunakan untuk pemindahan darah. Norhalim Haji Ibrahim, Perubatan Tradisional, Shah Alam, Fajar Bakti, 1997, hlm. 20.

3 Benda-benda tidak bernyawa adalah seperti gading gajah benar (gading gajah yang betul bukan herba), terisa (batang kayu balak) yang lama terendam di dasar sungai besar dan sebagainya. Harun Mat Piah, Kitabkitab Tib Koleksi Perpustakaan Negara Malaysia, Seminar Perubatan Melayu di Auditorium Akademi Pengajian Melayu Universiti Malaya 23-24 Ogos 2002, Anjuran Akademi Pengajian Melayu Universiti Malaya dengan kerjasama Kementeran Kesihatan Malaysia dan Dewan Bahasa dan Pustaka, hlm. 20.

4 Harun Mat Piah, Kitab Tib: Ilmu Perubatan Melayu, Kuala Lumpur: Perpustakaan Negara Malaysia, 2006, hlm. 35. Harun Mat Piah, 'Kitab Ubat Tradisional', Bengkel Kajian Naskah Kesultanan Melayu IV, 9-11 Ogos 2004, Anjuran Bahagian Kesusateraan Tradisional Dewan Bahasa dan Pustaka, hlm.14.

$5 \quad$ Kepercayaan animisme ini berasal daripada perkataan bahasa Latin iaitu anima yang mengandungi erti jiwa dan membawa pengertian tentang adanya jiwa bagi sesuatu yang maujud. Nurdeng Deuraseh, 
Pandangan Semesta Masyarakat Melayu Perspektif Perubatan Tradisional, International Journal of Social Policy and Society, vol. 7, 2010, hlm. 82.

Ibid.

Ibid.

Noor Azlan Mohd Noor, Penilaian Bahan-Bahan Penulisan Perubatan Melayu Tradisional: Satu Pengenalan Umum, Purba, 11,1992, hlm. 53.

9 Bomoh dirujuk sebagai 'specialist who tends the sick and cures illnesses'. Mohd. Taib Osman, 'The Bomoh and the Practice of Malay Medicine' dalam, Bunga Rampai : Aspects Of Malay Culture, Kuala Lumpur : Dewan Bahasa dan Pustaka, 1988, hlm.149. Terdapat beberapa kategori bomoh misalnya 'Bomoh Serba Boleh', 'Bomoh Patah', 'Bomoh Jampi', 'Bomoh Resdung', 'Bomoh Akar Kayu', 'Bomoh Puaka' dan 'Bomoh Kayap'. Haliza Mohd Riji, Malay Traditional Medicine: Health, Disease and The Treatment In The Context Of Primary Health Care, dalam Manusia dan Masyarakat, Jilid 11, 1999, hlm. 97. John. D. Gimlette menyatakan juga bomoh ialah a person who practices the healing art by utilizing the magic art. John. D. Gimlette, Malay Poison and Charm Cures, Kuala Lumpur : Oxford University Press, 1971, hlm. 19.

10 Dukun merupakan ahli perubatan tradisional yang mahir menggunakan pelbagai bahan seperti tumbuh-tumbuhan, binatang, logam dan lain-lain. Mereka boleh merawat pelbagai jenis penyakit dan gangguan termasuk demam, sakit kepala, patah tulang, terkehel, santau, sihir dan hilang semangat. Amran Kasimin, Sihir : Suatu Amalan Kebatinan, Bangi, Selangor: Penerbit Universiti Kebangsaan Malaysia, 2009, hlm. 22.

11 Pawang ialah "magician expert in spells, talismans, drugs and some particular industry; a shaman who invokes ancestral spirits, Hindu gods, Arabian genie, and Allah to reveal the cause of illness or drought or pestilence and accept placatory sacrifices". Amran Kasimin, Sihir : Suatu Amalan Kebatinan, hlm. 20. Menurut Skeat, 'the pawang class perform magic practices in order to find ore, medicine crop, or ensure good takes of fish, etc. Walter William Skeat, Malay Magic, Singapore : Oxford University Press, 1984, hlm. 56. Endicott pula dalam bukunya An Analysis of Malay Magic menyebut terdapat perbezaan antara bomoh dan pawang iaitu 'the distinction signals a division between the curer-called the bomor- and other practitioners of the magical arts'. K.N. Endicott, An Analysis of Malay Magic, Singapore: Oxford University Press, 1991, hlm. 13.

Nurdeng Deuraseh, 'Pandangan Semesta Masyarakat Melayu Perspektif Perubatan Tradisional’,hlm. 83.

13 Ibid.

14 Jampi adalah susunan kata yang indah dan boleh memberi kesan kuasa atau kesaktian apabila dibacakan ke atas benda-benda tertentu. Amran Kasimin, Sihir: Suatu Amalan Kebatinan, hlm. 59.

15 Mantera merupakan rangakai kata yang diucapkan oleh mereka yang terlibat dalam upacara adat istiadat, rawatan tradisional dan seumpamanya. Perkataan mantera berasal daripada perkataan Sanskrit iaitu "mantra" yang bermaksud bentuk fikiran. Mantera adalah puisi Melayu tertua yang telah diserapi oleh unsur-unsur Hindu-Buddha dan 
Islam. Mahiden Sah, 'Cara Perubatan Tradisional Masyarakat Melayu Sarawak: Kajian Dari Perspektif Islam Di Daerah Simunjan', Latihan Ilmiah, Universiti Malaya,Kuala Lumpur, 1993, hlm. 21, 42-43. Selain itu, mantera dalam agama Hindu dianggap sebagai 'wahyu' dan tidak boleh diubah serta tidak boleh diajar kepada orang yang belum berhak. Hampir semua mantera Hindu dalam memuja atau menyeru tuhan menyebut perkataan 'Om'. Kata 'Om' atau 'ongkara' (Om-kara) merupakan simbol dan dianggap mempunyai kekuatan ghaib dan sakti. Contoh mantera menggunakan kata 'Om' terdapat dalam mantera mematahkan buatan orang:

Om Sivayanama Om

Om Siva Siva Sivayanama

Om sarva sakhti Sivayanama

Om sarwa sakhti Devinama

Om sarva nayaki Om

Om maha Bhatrakali Om

Om sanggara bayanggara Kali Om

Om sarva thasa nasakari

Jakama akkama kakkma

Kangkathari Devi Suvaya Om

Sila lihat Harun Daud, Ulit Mayang: Kumpulan Mantera Melayu,Kuala Lumpur: Dewan Bahasa dan Pustaka, 2004, hlm.xiii dan xiv. Lihat juga Nurdeng Deuraseh, 'Pandangan Semesta Masyarakat Melayu Perspektif Perubatan Tradisional', hlm. 83.

Perkataan serapah berasal daripada perkataan Hindu dan lebih banyak mengandungi unsur-unsur kehinduan yang menyebut tentang namanama tuhan Hindu, dewa-dewa dan perkataan lain yang mempunyai pengaruh Hindu. Bahasa yang digunakan dalam serapah pula lebih banyak memperlihatkan ayat-ayat kutukan, sumpahan atau ancaman dengan tujuan yang sama seperti jampi dan mantera. Tujuannya adalah untuk menghalau makhluk halus yang menganggu manusia. Mahiden bin Sah, 'Cara Perubatan Tradisional Masyarakat Melayu Sarawak: Kajian Dari Perspektif Islam di Daerah Simunjan', hlm. 44. Ibid., hlm. 61.

18 Pisol Maidin, Konsep Kesihatan dan Entnofarmakologi: Satu kajian Falsafah Berdasarkan Beberapa Naskah Manuskrip Perubatan Tradisional (Bustan Al-Salatin, KItab Tib dan Taiyib al-ihsan), Disertasi M.Sc., Fakulti Sains, Universiti Malaya, 1995, hlm. 22.

Harun Mat Piah, Kitab Tib; Ilmu Perubatan Melayu, Kuala Lumpur: Perpustakaan Negara Malaysia, 2006, hlm. 22.

20 Syeikh Nuruddin ar-Raniri atau nama penuhnya Syeikh Nuruddin Muhammad ibn Ali Hamid ar-Raniri adalah seorang yang berketurunan Quraish yang telah dilahirkan di Ranir, Gujerat India. Beliau yang begitu terkenal dalam bidang ilmu sufi dipercayai telah mempelajari bahasa Melayu di Gujerat lebih-lebih lagi pada masa itu bahasa Melayu telah menjadi lingua franca di Alam Melayu dan mendapat tempias di negara-negara sekitarnya. Kemungkinan juga beliau sempat mempelajari 
bahasa Melayu daripada pelajar-pelajar Melayu yang berada di tanah suci Mekah ketika beliau menunaikan haji di sana pada tahun $1030 \mathrm{H}$ (1620M). Kemudian beliau telah datang ke Acheh sekitar 6 Muharam 1047H bersamaan 31 Mei 1637 iaitu semasa pemerintahan kerajaan Sultan Iskandar Thani tetapi tidak menetap di Acheh. Beliau terus ke Semenanjung Tanah Melayu dan di sinilah beliau memperdalamkan kefahaman beliau terhadap bahasa dan karya penulisan Melayu yang telah sedia ada seperti Hikayat Iskandar Dzulkarnain, Taj al- Salatin dan Sejarah Melayu. Disebabkan keakraban beliau dengan Sultan Iskandar, beliau telah mendapat kedudukan yang agak istimewa iaitu sebagai ulama dan penasihat sultan bagi menggantikan tempat Syeikh Syamsuddin Pasai yang telah meninggal dunia. Lihat Bustan al-Salatin II, hlm. ix dan hlm. xxxviii. Lihat juga G.W.J. Drewes, "Nuruddin al-Raniri Hujjat al-Siddiq li-daf' al-Zindiq", JMBRAS, vol.47. part 2, 1947, hlm. 82.

MSS 1076, Bustan al-Salatin, Bab 7 fasal 3 ini tersimpan di Perpustakaan Negara Malaysia. Keterangan tentang perubatan Melayu bermula dari halaman 56 hingga 109 (53 halaman) daripada keseluruhan Bab 7. Kitab tib yang telah disalin sekitar tahun 1830 tanpa nama penyalin dan tempat salinan juga membincangkan tentang kebajikan dan kejahatan segala manusia, ilmu firasat, memilih calon isteri dan pergaulan suami isteri. Terdapat satu lagi salinan yang hampir sama isi kandungannya di bawah tajuk Bustan al-Salatin MSS 3029 Bab 7 simpanan Perpustakaan Negara Malaysia yang mengandungi 62 halaman berkaitan perubatan Melayu. Sila lihat MSS 1076, Bustan al-Salatin, Bab 7 fasal 3 (jawi), Pusat Manuskrip Melayu, Perpustakaan Negara Malaysia, Kuala Lumpur. Juga lihat Bustan al-Salatin MSS 3029 Bab 7 fasal 3 (jawi), Pusat Manuskrip Melayu, Perpustakaan Negara Malaysia, Kuala Lumpur. Selepas ini disebut MSS 1076, Bustan al-Salatin sahaja. MSS 1076, Bustan al-Salatin, hlm. 73.

23 Nama asal Ibn Sina ialah al-Husain b. Abdullah b. Ali bin Sina atau Abu Ali. Beliau telah dilahirkan di Bukhara pada $980 \mathrm{M}(370 \mathrm{H})$ dan terkenal sebagai Avicenna di dunia barat. Arnida A. Bakar, " Terjemahan dan Ilmu Perubatan Islam: al-Qanun fi al-Tib Karya Ibn Sina", dalam Nik Salida Suhaila Nik Saleh (eds.), Sains Islam Merentasi Zaman, Negeri Sembilan: USIM, 2007, hlm. 81.

24 Ibid.

25 Manuskrip Ilmu Tabib ini telah dibuat transliterasi oleh A. Samad Ahmad dan diterbitkan atas judul Warisan Perubatan Melayu oleh DBP pada 1982. Namun beliau tidak mencatatkan kod bagi manuskrip yang digunakan ini. Kelihatan manuskrip ini tidak diselesaikan transliterasinya kerana tidak terdapat tarikh salinan di penghujung manuskrip. Cuma di bahagian pendahuluan buku, A.Samad Ahmad memaparkan penghujung manuskrip yang mencatat nama penyalinnya iaitu Muhammad Salleh ibn Ahmad Penambang pada 1288H bersamaan 1872 di Kota Raja Kelantan. Manakala salinan manuskrip Kitab Tib 1714 yang mempunyai isi yang sebahagiannya hampir sama dengan manuskrip Ilmu Tabib pula terdapat di Perpustakaan DBP. Manuskrip asalnya berada di Perpustakaan 
Universiti Leiden dengan judul Cod. Or. 1714 Kitab Tib. Kitab Tib 1714 dan Cod. Or. 1714 Kitab Tib yang berjumlah 502 halaman ini dikatakan selesai 'disurat' oleh Haji Zainal Abidin di Kampung Penhujan Betawi pada Khamis 1 Januari 1824. Manakala manuskrip Kitab Tib MSS 2515 yang mengandungi 218 halaman dan ditulis pada 1829 ini pula tersimpan di Perpustakaan Negara Malaysia. Catatan di sebelah kulit hadapan menyatakan bahawa penulis asal manuskrip ini ialah Ibrahim bin Muhamad Fabian dari Terengganu. Manuskrip ini telah ditransliterasi oleh Harun Mat Piah dan Zawiyah Baba. Harun Mat Piah dan Zawiyah Baba, Kitab Tib MSS 2515 Perpustakaan Negara Malaysia: Kajian Teks dan Suntingan, Bangi: UKM, 2014, hlm. 257-258. Selepas ini disebut Kitab Tib MSS 2515 sahaja. A. Samad Ahmad (diselenggarakan) Warisan Perubatan Melayu, Kuala Lumpur: Dewan Bahasa dan Pustaka, 1982. Lihat Kitab Tib 1714, Dewan Bahasa dan Pustaka Kuala Lumpur (salinan jawi) -selepas ini disebut Kitab Tib 1714 dan Cod. Or. 1714 Kitab Tib, (jawi) Perpustakaan Universiti Leiden, Netherlands - selepas ini disebut Cod. Or. 1714 Kitab Tib, (jawi). Kitab Tib MSS 2515, hlm. 340.

MSS 1076, Bustan al- Salatin, hlm. 78-79.

Bustan al-Salatin turut menerangkan penggunaan jenis tumbuhan yang mempunyai unsur dan khasiat yang berbeza-beza. Misalnya fawful iaitu pinang tua mempunyai unsur sejuk dan kering pada darjat yang ketiga dan berfungsi untuk menguatkan gigi. Jika pinang tua ini ditumbuk lumat-lumat serta digunakan sebagai celak, penyakit mata yang dihidapi oleh pesakit akan sembuh. MSS 1076, Bustan al-Salatin, hlm.83-84. Ibid., hlm.101.

A. Samad Ahmad (penyelenggara), Sulalat al-Salatin-Sejarah Melayu, hlm.135-136.

Namun akhirnya beliau meninggal dunia akibat bedilan peluru Portugis. A. Samad Ahmad (penyelenggara), Sulalat al-Salatin-Sejarah Melayu, hlm. 258, 269-270.

Misa Melayu, Ahmad Fauzi Mohd Basri (penyelenggara), Kuala Lumpur:Dewan Bahasa dan Pustaka, 1992, hlm. xli, 22, 27, 60-61.

Transliterasi teks Riwayat Kelantan ini boleh dilihat dalam tesis Zahir Ahmad, Kelantan: Analisis Teks, Interteks Dan Konteks, Thesis Ph.D.,Jabatan Pengajian Melayu, Fakulti Sastera dan Sains Sosial, Universiti Malaya, 1997, hlm. 412-552

Latipah bt. Omar, Perubatan Melayu Tradisional : Satu Kajian Mengenai Unsur-Unsur Khurafat Dalam Perbomohan : Satu Tinjauan Khusus Di Jajahan Bachok Kelantan, Latihan Ilmiah, Fakulti Usuluddin, Akademi Islam, Universiti Malaya, 1995/1996, hlm. 52.

A. Samad Ahmad (penyelenggara), Sulalat al-Salatin-Sejarah Melayu, hlm. 222-223.

36 Pawang Gajah ini berasal dari Kedah tetapi menetap di Terengganu. Munsyi Abdullah, Hikayat Abdullah, Kuala Lumpur: Pustaka Antara, 1997, hlm. 47-52. 
A. Samad Ahmad (penyelenggara), Sulalat al-Salatin-Sejarah Melayu, hlm. 46 dan 114.

Tuhfat al-Nafis: Naskhah Terengganu (jawi), Shaharil Talib et.al., (pengenalan), Terengganu: The House of Tengku Ismail, 1991, hlm. 97, 142. Selepas ini disebut Tuhfat al-Nafis: Naskhah Terengganu (jawi) sahaja. Tuhfat al-Nafis: Naskhah Terengganu (jawi), hlm. 142.

Siti Hawa Salleh (diselenggarakan), Hikayat Patani, Kuala Lumpur: Dewan Bahasa dan Pustaka, 1992, hlm. 3-7.

Mohd Taib Osman, Malay Folk Beliefs : An Integration of Disparate Elements, Kuala Lumpur: Dewan Bahasa dan Pustaka, 1989, hlm. 59. Hashim Awang A.R., Perbomohan Melayu: Ke mana Akhirnya? Purba, 15,1996, hlm. 61. Hashim Awang A.R., "Perbomohan Melayu: Ke mana Akhirnya?" hlm. 61.

Zubaidah Bt. Sidek, Peranan Jampi Serapah Dan Doa-Doa Dalam Perubatan Tradisional : Satu Kajian di Bachok, Kelantan, Latihan Ilmiah, Fakulti Usuluddin, Akademi Islam Universiti Malaya, 1994, hlm. 27.

Antara manuskrip perubatan Melayu yang terdapat di Perpustakaan DBP adalah Kitab Ilmu Perubatan (MS 33), Kitab Ilmu Perubatan (MS 47), Kitab Tib 1714, Buku Raksi, Buku Doa dan Jampi dan lain-lain lagi.

Kitab Tib MSS 2515, hlm.114-161.

Ibid., hlm.114-161. Ubat demam dicatatkan juga di halaman lain iaitu pada halaman 244-246.

Ibid., hlm. 131.

Ibid., hlm. 317- 323.

Keterangan mengenai penyakit demam dalam Cod. Or. 1714 Kitab Tib adalah sebanyak 13 halaman, manakala kitab Imu Tabib pula sebanyak lima halaman. Bagi semua jenis deman boleh rujuk Cod. Or. 1714 Kitab Tib (jawi), hlm. 47-67. A. Samad Ahmad, Warisan Perubatan Melayu, hlm. 24-28.

Cod. Or. 1714 Kitab Tib (jawi), hlm. 47. A. Samad Ahmad, Warisan Perubatan Melayu, hlm. 24. Kedua-dua manuskrip ini menyebut rawatan yang sama, cuma berbeza dari segi tanda koma, beberapa perkataan dan lain-lain lagi. Tanda ( ) menunjukkan perkataan tersebut ditulis dalam Ilmu Tabib. Tanda \{ \} menunjukkan perkataan tersebut ditulis dalam Cod. Or. 1714 Kitab Tib (jawi).

Cod. Or. 1714 Kitab Tib (jawi), hlm. 46. Dalam kitab Ilmu Tabib, tanda tersebut adalah tanda atau perkataan seperti ra dan waw. A. Samad Ahmad, Warisan Perubatan Melayu, hlm. 21.

Kitab Tib MSS 2515, hlm. 234-240.

Ibid., hlm. 237.

Cod. Or. 1714 Kitab Tib (jawi), hlm. 63-70. A. Samad Ahmad, Warisan Perubatan Melayu, hlm. 33.

A. Samad Ahmad, Warisan Perubatan Melayu, hlm. xiv.

Kitab Tib MSS 2515, hlm.185-199, 202-221, 229-234; Cod. Or. 1714 Kitab Tib, hlm. 151-162,174-177, 295-296, 299-300, 332-335 A. Samad Ahmad, Warisan Perubatan Melayu, hlm. 40-43, 55-58, 70-72.

A. Samad Ahmad, Warisan Perubatan Melayu, hlm.112-118. 
Amran Kasimin, Sihir: Suatu Amalan Kebatinan, hlm. 59.

Ibid.

Kitab Tib MSS 2515, hlm. 182.

Cod. Or. 1714 Kitab Tib (jawi), hlm. 215-216. A. Samad Ahmad, Warisan Perubatan Melayu, hlm.113. Kedua-dua manuskrip ini menyebut mantera yang sama, cuma berbeza dari segi tanda koma, sebutan beberapa perkataan dan lain-lain lagi. Tanda ( ) menunjukkan perkataan tersebut ditulis dalam Ilmu Tabib. Tanda \{\} menunjukkan perkataan tersebut ditulis dalam Cod. Or. 1714 Kitab Tib (jawi).

Cod. Or. 1714 Kitab Tib (jawi), hlm. 310. A. Samad Ahmad, Warisan Perubatan Melayu, hlm. 116-117.

Pisol Maidin, Konsep Kesihatan dan Entnofarmakologi: Satu kajian Falsafah Berdasarkan Beberapa Naskah Manuskrip Perubatan Tradisional, Bustan Al-Salatin, Kitab Tib dan Taiyib al-Ihsan, Disertasi Sarjana, Fakulti Sains, Universiti Malaya, 1995, hlm.27-28.

Hashim Awang A.R., "Perbomohan Melayu: Ke mana Akhirnya?"hlm. 57.

Norihan Hamzah, 'Bomoh Melayu: Konsep, Asal Usul dan Perkembangan Perubatan Melayu,' Latihan Ilmiah, Jabatan Pengajian Melayu, Universiti Malaya, 1994, hlm. 29-30.

Norhalim Haji Ibrahim, Perubatan Tradisional, Shah Alam: Penerbit Fajar Bakti Sdn. Bhd., hlm.15.

Abdul Razak Abdul Karim, Kitab Perubatan Mujarrabat: Khasiat Ayat-Ayat Al-Quran dan Rawatan Tradisional, Seminar dan Pameran Perubatan Melayu (23-24 Ogos 2002 : Kuala Lumpur), hlm. 6.

Ibid.

Ibid., hlm. 6-8.

Noraini Mohamed Hassan, 'Perkembangan Jabatan Perubatan Persekutuan, 1896-1910', Jurnal Sejarah, No. 21, 2013, hlm. 16.

F. A. Swettenham, British Malaya: An Account of the Origin and Progress of British Influence in Malaya, London: Allen and Unwin, 1955, hlm. 155. Keterangan lanjut mengenai perkhidmatan dispenasari, sila rujuk Sofiah Othman, Perkhidmatan Dispensari Negeri-negeri Selat, 1897-1941, Projek Ilmiah Jabatan Sejarah Universiti Malaya, 2012/13. Ahmad Kamal Ariffin Mohd. Rus dan Suffian Mansor, 'Proses Transisi Masyarakat Melayu di Tanah Melayu, 1880-1941: Reaksi Terhadap Perkembangan Kemajuan Infrastruktur dan Sistem Kesihatan Awam' dalam Arba'iyah Mohd Noor dan Mohammad Reduan Othman et al., Persada Jauhari, Kuala Lumpur: Penerbit Universiti Malaya, 2012, hlm. 52. Noraini Mohamed Hassan, Perkembangan Jabatan Perubatan Persekutuan, 1896-1910, hlm. 1-2. Noor Azlan Mohd Noor, Penilaian Bahan-Bahan Penulisan Perubatan Melayu Tradisional: Satu Pengenalan Umum, hlm. 54-55.

Ahmad Kamal Ariffin Mohd. Rus dan Suffian Mansor, 'Proses Transisi Masyarakat Melayu di Tanah Melayu, 1880-1941, hlm. 53.

F. A. Swettenham, British Malaya, hlm. 155. 
75 Wan Faizah Meor Ibrahim, Isu-isu Wanita Dalam Beberapa Akhbar Melayu Tahun 1920-1940, Disertasi, Sarjana Jabatan Sejarah, Kuala Lumpur: Universiti Malaya, 2008/09, hlm. 131.

76 Ibid., hlm. 112.

77 Annual Report of the Straits Settlements 1855-1941. Vol.8: 1922-1926, hlm. 394, 530, 662; Annual Report of the Straits Settlements 1855-1941. Vol.9: 1927-1934, hlm. 141, 295, 408, 539, 622.

$78 \quad$ F. A. Swettenham, British Malaya, hlm. 155.

79 Ibid., hlm. 156.

80 Mohamad Hanafi Mohd Lotfi, Dasar pentadbiran British di Melaka, 19001920: Kesan Terhadap Perkembangan Masyarakat Melayu, Latihan Ilmiah (B.A), Jabatan Sejarah, Fakulti Sastera dan Sains Sosial, Universiti Malaya, 2010/2011. hlm. 85. Ahmad Kamal Ariffin Mohd. Rus dan Suffian Mansor, 'Proses Transisi Masyarakat Melayu di Tanah Melayu, 1880-1941, hlm. 53-54. 